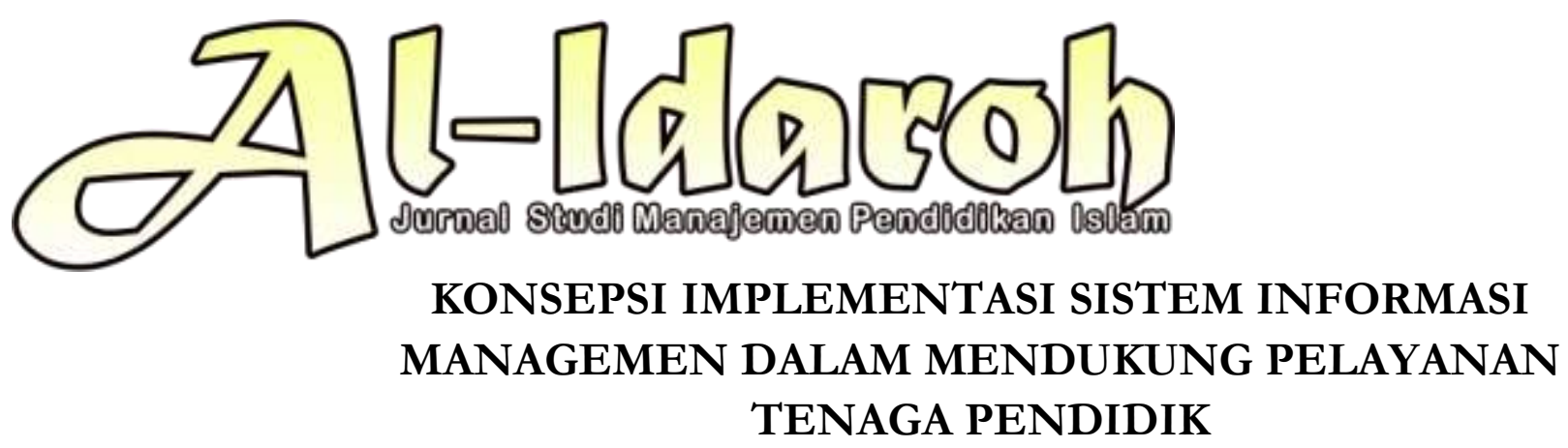

\author{
Ali Mustofa \\ Prodi Pendidikan Agama Islam, STIT al Urwatul Wutsqo Jombang \\ Email: aljep_90@yahoo.com
}

Andi Prayoga

Prodi Manajemen Pendidikan Islam, STIT al Urwatul Wutsqo Jombang Email: andyyoga1999@gmail.com

\begin{abstract}
The use of management information systems in the field of education (SIMDIK) is very important in management, both in terms of managing academic administration, staffing administration, administration of facilities and infrastructure, reporting administration and so on. However, managing the administrative staff is more prioritized in educational institutions, especially teaching staff because they are the most important element in the education process. The use of management information system as a service system for teaching and education staff will be managed and empowered through SIMPATIKA (Information System for Educators and Education Personnel of the Ministry of Religion). It is helpful the management of teaching and educational staff, although some weaknesses in it. SIM is not only necessary but it is used to realize the vision, improve the educators and educational staff quality in accordance with the educators and education standards. So the use of SIM is as a mandatory step to carry out its mission. SIM maintenance should be prioritized to serve educators and education staff so it realizes the educators and educational staff quality in accordance with the educators and education standards.
\end{abstract}

Keyword: management information system, educator services

\title{
Pendahuluan
}

Kemajuan ilmu pengetahuan di berbagai bidang seperti perusahaan, organisasi, maupun pendidikan adalah akibat dari berkembangnya teknologi informasi. Perkembangan teknologi adalah sesuatu yang tidak dapat dihindari dalam kehidupan manusia. Mulai dari berkomunikai, mengirim pesan atau surat, bahkan transaksi jual beli dapat dilakukan dengan dukungan teknologi. Karena teknologi akan berjalan sesuai ilmu pengetahuan yang diciptakan oleh manusia berdasarkan inovasi yang didapat ketika manusia mengalami kesulitan dalam menghadapi permasalahan didalam kehidupannya. 
Ali Mustofa

Andik Prayugo

Dalam dunia pendidikan, yang dibutuhkan adalah sebuah teknologi yang dapat mendukung pelayanan informasi secara efektif dan efisien. Melihat banyaknya data yang harus dikelola dan diselesaikan dengan tepat waktu, maka diperlukan sebuah tindakan yang dapat memberikan hasil maksimal dan tepat waktu.

Maka dari itu, dunia pendidikan memerlukan sebuah strategi berupa pemanfaatan teknologi informasi yang dapat diaplikasikan sebagai sarana komunikasi untuk meningkatkan kinerja dunia pendidikan secara signifikan. Bukan hanya sebagai pendukung saja, melainkan sebagai faktor utama dalam mendukung dunia pendidikan untuk bersaing di pasar global. Teknologi informasi yang dimaksud adalah Sistem Informasi Managemen(SIM)yang mempunyai manfaat yaitu, meningkatkan efisiensi dan efektivitas data secara akurat dan realtime, meningkatkan kualitas sumber daya manusia, karena unit sistem kerja yang terkoordinasi dan sistematis, meningkatkan produktivitas dan penghematan biaya dalam organisasi.

Pemanfaatan sistem informasi manajemen dalam bidang pendidikan yang biasa disebut SIMDIK sudah sangat diperlukan dalam pengelolaan, baik dalam hal pengelolaan administrasi akademik, administrasi kepegawaian, administrasi sarpras, administrasi pelaporan dsb. Namun yang sering diprioritaskan di lembaga pendidikan adalah dalam hal pengelolaan administrasi kepegawaian khususnya tenaga pendidik sebab tenaga pendidik merupakan unsur terpenting dalam proses pendidikan. Kualitas pendidikan yang baik berawal dari proses pembelajaran yang dilakukan guru kepada peserta didik didalam kelas. Hal ini dapat dilihat dalam undang-undang sistem pendidikan nasional nomor 20 tahun 2003, yaitu tugas dan tanggung jawab pendidik dan tenaga kependidikan, dalam upaya mencerdaskan anak bangsa. Oleh karena itu, keberhasilan lembaga pendidikan dalam memberikan layanan pendidikan tergantung dari pengelolaan tenaga pendidik dan kependidikan.

Sistem informasi Pendidik dan Tenaga Kependidikan Kementrian Agama (SIMPATIKA) adalah sistem informasi managemen berbasis web yang digunakan oleh madrasah di Indonesia untuk mengelola pendidik dan tenaga kependidikannya. SIMPATIKA memiliki beberapa fitur untuk membantu kepentingan tenaga pendidik diantaranya; Digitalisasi Portofolio PTK, Beasiswa PTK, Tunjangan PTK, Diklat PTK, Sertifikasi PTK, Alih Tugas Tambahan, SKMT \& SKBK Online, Seleksi Sertifikasi Guru Kemenag, Registrasi UKG, eTunjangan, Tata Kelola Pengawas, 


\section{Konsepsi Implementasi Sistem Informasi Managemen dalam Mendukung Pelayanan Tenaga Pendidik}

ePKB (tindak lanjut hasil UKG), dan beragam program lainnya. Proses transaksi data pada Layanan SIMPATIKA akan melibatkan secara berjenjang mulai dari individu PTK, Pimpinan Madrasah/Sekolah, Kantor Kemenag Kab/Kota, Kantor Wilayah Kemenag Provinsi, hingga Unit-Unit Kerja Kemenag Pusat dengan terpadu.

Namun di balik manfaat fitur-fitur yang disediakan Kemenag pada SIMPATIKA, Irjen Kemenag menemukan beberapa kelemahan, salah satunya adalah absensi guru masih dilakukan secara manual. Hal tersebut juga dibuktikan dengan hasil rekapan data guru penerima TPG tidak terbit bulan Januari s.d Mei 2019 oleh Kepala Kemenag Jombang dikarenakan beberapa madrasah yang ada di Kabupaten Jombang tidak mengisi absen di SIMPATIKA. (Ahmad. Kelemahan-kelemahan tersebut bukan menjadi alasan bagi para pengelola Madrasah untuk tidak menggunakan SIM dalam pengelolaannya. Karena penggunaan SIMPATIKA merupakan suatu kebijakan dari Kementrian Agama yang harus jalani oleh setiap Madrasah.

\section{Pembahasan}

\section{A. Implementasi}

Implementasi adalah suatu tindakan atau pelaksanaan dari sebuah rencana yang sudah disusun secara matang dan terperinci. Implementasi biasanya dilakukan setelah perencanaan sudah dianggap sempurna. Menurut Nurdin Usman, implementasi adalah bermuara pada aktivitas, aksi ,tindakan atau adanya mekanisme suatu sistem, implementasi bukan sekedar aktivitas, tapi suatu kegiatan yang terencana dan untuk mencapai tujuan kegiatan'1. Guntur Setiawan berpendapat, implementasi adalah perluasan aktivitas yang saling menyesuaikan proses interaksi antara tujuan dan tindakan untuk mencapainya serta memerlukan jaringan pelaksana,birokrasi yang efektif ${ }^{2}$

Berdasarkan pendapat para ahli diatas maka dapat disimpulkan implementasi adalah suatu kegiatan yang terencana, bukan hanya suatu aktifitas dan dilakukan secara sungguh-sungguh berdasarkan acuan norma-norma tertentu untuk mencapai tujuan kegiatan. Oleh karena itu, implementasi tidak berdiri

${ }^{1}$ Usman, N. Konteks Implementasi Berbasis Kurikulum.(Jakarta: aja Grafindo Persada, 2002), 40

${ }^{2}$ Setiawan, Guntur. Implementasi dalam Birokrasi Pembangunan. (Jakarta: BalaiPustaka.2014), 23. 
Ali Mustofa

Andik Prayugo

sendiri tetapi dipengaruhi oleh objek berikutnya yaitu kurikulum. Implementasi kurikulum merupakan proses pelaksanaan ide,program atau aktivitas baru dengan harapan orang lain dapat menerima dan melakukan perubahan terhadap suatu pembelajaran dan memperoleh hasil yang diharapkan Implementasi mencakup tiga aspek, yaitu;

1. Perencanaan

Perencanaan merupakan salah satu syarat mutlak bagi setiap kegiatan administrasi. Tanpa perencanaan atau planning pelaksanaan suatu kegiatan akan mengalami kesulitan dan bahkan mengalami kegagalan dalam mencapai tujuan yang diinginkan. ${ }^{3}$

2. Pelaksanaan

Pelaksanaan adalah suatu tindakan atau pelaksanaan dari sebuah rencana yang sudah disusun secara matang dan terperinci, implementasi biasanya dilakukan setelah perencanaan sudah dianggap siap. Secara sederhana pelaksanaan bisa diartikan penerapan. Majone dan Wildavsky mengemukakan pelaksanaan sebagai evaluasi. Browne dan Wildavsky mengemukakan bahwa Pelaksanaan adalah perluasan aktivitas yang saling menyesuaikan ${ }^{4}$

3. Evaluasi

Evaluasi merupakan penilaian terhadap hasil kerja yang telah dilaksanakan. Hasil penilaian, dijadikan sebagai acuan dalam melakukan perbaikan dan penyempurnaan, untuk mencapai tujuan yang telah ditetapkan ${ }^{5}$.

\section{B. Sistem Informasi Manajemen (SIM)}

1. Pengertian Sistem Informasi Manajemen

Sistem dapat didefinisikan sebagai sekelompok elemen yang terintegrasi dengan maksud yang sama untuk mencapai suatu tujuan. Hal pertama yang perlu diperhatikan dalam suatu sistem adalah elemen-elemenya. Tentunya setiap sistem memiliki elemen-elemennya sendiri, yang kombinasinya

${ }^{3}$ Ngalim Purwanto, S. D. . Administrari Pendidikan.(Jakarta: Mutiara Sumber Widya., 1998), 24

${ }^{4}$ Usman, N. Konteles Implementasi Berbasis Kurikulum.(Jakarta: aja Grafindo Persada, 2002), 40

${ }^{5}$ H. Muwaid Shulhan, S. Managemen Pendidikan Islam. Yogyakarta: Kalimedia. 2018), 25 
berbeda antara sistem yang satu dengan yang lain. Namun demikian, susunan dasarnya tetap sama.

Sistem Informasi Manajemen (Selanjutnya disebut SIM) merupakan penerapan sistem informasi didalam organisasi untuk mendukung informasiinformasi yang dibutuhkan oleh semua tingkatan manajemen ${ }^{6}$. Sistem Informasi Manajemen mengandung arti sekumpulan orang, seperangkat pedoman dan pemilihan peralatan pengolahan data, menyimpan, mengolah dan memakai data untuk mengurangi ketidakpastian dalam pengambilan keputusan dengan memberikan informasi kepada manajer agar dapat dimanfaatkan pada waktunya secara efesien ${ }^{7}$

Beberapa ahli juga mengartikan Sistem Informasi Manajemen sebagai berikut:

a. Barry E. Cushing

SIM adalah sekumpulan dari manusia dan sumber-sumber daya modal didalam suatu organisasi yang bertanggungjawab mengumpulkan dan mengolah data untuk menghasilkan informasi yang berguna untuk semua tingkatan manajemen didalam kegiatan perencanaan dan pengendalian.

a. Gordon B. Davis

SIM adalah sistem manusia atau mesin yang menyediakan informasi untuk mendukung operasi manajemen dan fungsi pengambilan keputusan dari suatu organisasi ${ }^{8}$

b. Raymond Mc. Leod Jr

SIM merupakan suatu sistem berbasis komputer yang menyediakan informasi bagi beberapa pemakai yang mempunyai kebutuhan yang serupa. ${ }^{9}$

Tim Dosen Administrasi Pendidikan Universitas Pendidikan Indonesia menyimpulkan bahwa Sistem Informasi Manajemen (SIM) mempunyai karakteristik, diantaranya:

a. Dalam organisasi terdapat satu bagian khusus sebagai pengelola SIM pendidikan

${ }^{6}$ Lantip Diat Prasojo, Sistem informai Managemen Pendidikan. (Yogyakarta:UNY PRESS. 2013), 10

7Siagian, Harbangan, Administrasi Pendidikan. (Semarang; Satya Wacana. 1989), 20.

${ }^{8}$ Prasojo, Lantip Diat Sistem informai Managemen Pendidikan. (Yogyakarta:UNY PRESS. 2013) 45.

${ }_{9}^{9}$ Moekijat. Pengantar Sistem Informasi Manajemen. (Bandung: Mandar Maju, 2005), $35 .$. 
Ali Mustofa

Andik Prayugo

b. SIM merupakan jalinan lalu lintas data dan informasi dari setiap bagian di dalam bagian dalam organisasi yang terpusat di bagian SIM pendidikan

c. SIM merupakan jalinan hubungan antar bagian dalam organisasi melalui satu bagian SIM

d. SIM merupakan segenap proses yang mencakup: pengumpulan data, pengolahan data, Penyimpanan data, Pengambilan data, Penyebaran informasi dengan cepat dan tepat.

e. SIM bertujuan agar para pelaksana dapat melaksanakan tugas dengan baik dan benar serta pemimpin dapat mengambil keputusan dengan cepat dan tepat. ${ }^{10}$

Dari beberapa pengertian di atas, dapat disimpulkan bahwa Sistem Informasi Manajemen merupakan merupakan jaringan prosedur pengolahan data yang dikembangkan dalam suatu organisasi dan disahkan bila diperlukan untuk memberikan data kepada manajemen untuk dasar pengambilan keputusan dalam rangka mencapai tujuan.

2. Tujuan Sistem Informasi Manajemen

Sistem informasi manajemen memiliki tujuan merancang dan mengimplementasikan prosedur, proses, dan rutinitas yang memberikan laporan sesuai rinci secara akurat, konsisten dan juga tepat waktu. Berikut ini beberapa tujuan dari sebuah sistem informasi manajemen:

a.Menangkap Data

Salah satu tujuan dari sistem informasi manajemen yaitu untuk menangkap data kontekstual atau informasi operasional yang akan berkontribusi dalam mengambil suatu keputusan dari berbagai sumber internal dan eksternal organisani.

b. Pengolahan Data

Tujuan sistem informasi yang kedua yaitu untuk pengolahan data. Data yang akan diolah menjadi informasi yang diperlukan sebagai perencanaan, pengorganisasian, koordinasi, memimpin dan mengendalikan fungsi pada tingkat yang strategis, taktis dan operasional. Pengolahan ata ini meliputi:

10 Tim Dosen Administrasi Pendidikan Universitas Pendidikan Indonesia ManajemenPendidikan. (Bandung: Alfabeta. 2009).30 


\section{Konsepsi Implementasi Sistem Informasi Managemen dalam Mendukung Pelayanan Tenaga Pendidik}

Membuat perhitungan dengan menggunakan data data Mengklarifikasikan data.

c.Penyimpanan, Penggunaan dan Penyebaran Informasi

Semua informasi dan data yang diolah harus disimpan untuk digunakan dimasa yang akan datang. Selain itu, sistem juga harus dapat mengambil informasi ini dari penyimpanan bila diperlukan pada berbagai penggunaan. Kemudian dari informasi tersebut atau produk jadi dari MIS harus diedarkan pada semua penggunanya secara berkala dengan menggunakan jaringan organisasi.

3. Peran Sistem Informasi Managemen

Sistem informasi dimanfaatkan oleh para pemakai layanan informasi guna membantu tugas penentuan kebijakan organisasi bagi para kepala sekolah. Keberadaan sistem informasi manajemen pada ujungnya berfungsi untuk menelaah informasi menjadi bahan pengambilan keputusan. Selain informasi dapat diperoleh melalui sistem ini, informasi juga bisa diperoleh dari informasi luar. Seorang kepala sekolah seringkali kelebihan informasi, namun tidak semua informasi yang diterima adalah informasi yang baik dan relevan dengan organisasi, akibatnya kurang akurat informasi tersebut, manajer cenderung mengalami kesalahan saat menentukan kebijakan.

Sistem informasi manajemen bertugas menyaring berdasarkan keperluan organisasi, yang orientasinya untuk menunjang keefektifan pengambilan keputusan dari kepala sekolah. Salah satu tugas penting seorang kepala sekolah adalah pengambilan keputusan yang berkenaan dengan lembaga pendidikan. Sebagai bahan pijakan pengambilan keputusan bagi kepala sekolah adalah sistem informasi manajemen. Suatu informasi bisa menjadi bahan bagi pengambil keputusan dalam tahapan tertentu, tetapi bisa pula merupakan bahan mentah bagi pengambil keputusan untuk tahapan berikutnya ${ }^{11}$.

${ }^{11}$ Syamsi, Ibnu, Pengambilan Keputusan dan Sistem Informasi. (Jakarta: Bumi Aksara. 1995),65 
Ali Mustofa

Andik Prayugo

\section{Pelayanan Tenaga Pendidik}

1. Pelayanan

Dalam mengembangkan dan meningkatkan kualitas sumber daya manusia jasa pendidikan memegang peranan penting. Keberhasilan jasa pendidikan ditentukan dalam memberikan pelayanan yang berkualitas kepada para pengguna jasa pendidikan tersebut (siswa, stakeholder, masyarakat).

Pelayanan menurut Kamus Besar Bahasa Indonesia (KBBI) adalah sebagai suatu usaha untuk membantu menyiapkan atau mengurus apa yang diperlukan orang lain. Sedangkan menurut Daviddow dan Uttal dalam Sutopo dan Suryanto bahwa Pelayanan merupakan usaha apa saja yang meningkatkan kepuasan pelanggan. Thoha menjelaskan bahwa tugas pelayanan lebih menekankan kepada mendahulukan kepentingan umum, mempermudah urusan publik dan mempersingkat waktu proses. Sedangkan tugas mengatur lebih menekankan kepada kepuasan atau power yang melekat pada posisi jabatan birokrasi. Lebih lanjut Pasolong berpendapat bahwa pelayanan pada dasarnya dapat didefinisikan sebagai aktivitas seseorang, sekelompok, dan organisasi baik langsung maupun tidak langsung untuk memenuhi kebutuhan.

Berdasarkan teori para ahli tersebut di atas, maka pelayanan adalah suatu kegiatan atau tindakan yang dilakukan oleh penyelenggara pelayanan baik berupa barang ataupun jasa yang menghasilkan manfaat bagi penerima layanan.

2. Tenaga Pendidik

Rancangan Peraturan Pemerintah (RPP) BAB XII, Tahun 2005 Pasal 139, Pasal 1 dinyatakan bahwa pendidik mencakup guru, dosen, konselor, pamong belajar, pamong widyaiswara, tutor, instruktur, fasilitator, pelatih, dan sebutan lain dari profesi yang berfungsi sebagai agen pembelajaran peserta didik. Di dalam Peraturan Pemerintah Nomor 19 Tahun 2005 Tentang Standar Nasional Pendidikan, Bab VI, pasal 28 dinyatakan bahwa Kompetensi sebagai agen pembelajaran pada jenjang pendidikan dasar dan menengah serta pendidikan anak usia dini meliputi, kompetensi: pedagogik, kepribadian, profesional, dan social. ${ }^{12}$

${ }^{12}$ Sulistriyorini, Manajemen Pendidikan Islam. (Bandung: Elka, 2006), 30 


\section{Konsepsi Implementasi Sistem Informasi Managemen dalam Mendukung Pelayanan Tenaga Pendidik}

Pendidik merupakan tenaga profesional yang bertugas merencanakan dan melaksanakan proses pembelajaran, menilai hasil pembelajaran, melakukan pembimbingan dan pelatihan, serta melakukan penelitian dan pengabdian kepada masyarakat, terutama bagi pendidik pada perguruan tinggi. (UndangUndang Sistem Pendidikan Nasional No 20 Tahun 2003 Pasal 39 ayat 2).Sedangkan menurut Ahmad Tafsir yang dikemukan oleh Sulistiyorini di dalam bukunya, pendidik dalam Islam adalah orang-orang yang bertanggung jawab terhadap perkembangan anak didik dengan mengupayakan perkembangan seluruh potensi anak didik, baik potensi afektif, potensi kognitif, maupun potensi psikomotorik.

Hak dan Kewajiban Pendidik dan Tenaga Kependidikan UndangUndang No 20 tahun 2003 tentang Sistem Pendidikan Nasional pasal 40, dinyatakan bahwa hak dan kewajiban pendidik adalah sebagai berikut: 1 . Pendidik adalah tenaga kependidikan berhak memperoleh :

a. Penghasilan dan Jaminan kesejahteraan sosial yang pantas dan memadai;

b. Penghargaan sesuai dengan tugas dan prestasi kerja;

c. Pembinaan karir sesuai dengan tuntutan pengembangan kualitas;

d. Perlindungan hukum dalam melaksanakan tugas dan hak atas hasil kekayaan intelektual;

e. Kesempatan untuk menggunakan sarana, prasarana, dan fasilitas pendidikan untuk menunjang kelancaran pelaksanaan tugas.

Selanjutnya pada pasal 43, hak lain yang akan diperoleh pendidik adalah promosi dan sertifikasi, yakni :

a. Promosi dan penghargaan bagi pendidik dan tenaga kependidikan dilakukan berdasarkan latar belakang pendidikan, pengalaman, kemampuan, dan prestasi kerja dalam bidang pendidikan;

b. Sertifikasi pendidik dilselenggarakan oleh perguruan tinggi yang memiliki program pengadaan tenaga kependidikan yang terakreditasi;

c. Ketentuan mengenai promosi, penghargaan, dan sertifikasi pendidik sebagaimana dimaksud dalam ayat (1) dan ayat (2) diatur lebih lanjut dengan peraturan pemerintah. 
Ali Mustofa

Andik Prayugo

3. Bentuk Layanan Pendidikan

Layanan yang ditawarkan lembaga dapat ditingkatkan melalui unsur kualitas jasa. Lembaga pendidikan merupakan organisasi yang memberikan pelayanan kepada Stakeholder internal dan eksternal. Stakeholder internal terdiri dari semua lembaga di dalam sekolah (seperti yayasan, program studi, dan unit kegiatan siswa) dan para aktor yang berada di dalamnya (seperti siswa, guru, tata usaha, dan staf yang lain). Stakeholder eksternal terdiri dari alumni, orang tua siswa, pemerintah, dan masyarakat umum. Keberhasilan sekolah diukur dari tingkat kepuasan pelanggan, baik internal maupun eksternal. Sekolah dikatakan berhasil jika mampu memberikan pelayanan 24 sama atau melebihi harapan pelanggan, karena mereka sudah mengeluarkan butged cukup banyak pada lembaga pendidikan.

Bentuk pelayanan dalam lembaga pendidikan ada dua ${ }^{13}$ di antaranya adalah :

a.Layanan pokok

Dalam memenuhi kebutuhan siswa yang berhubungan dengan pelayanan siswa di sekolah, dalam menjalankan tugasnya kepala sekolah dibantu oleh para personil profesional sekolah yang dipekerjakan pada sistem sekolah di antaranya adalah:

1) Personil pelayanan pengajaran

Terdiri dari orang-orang yang bertanggung jawab pokoknya ialah mengajar, baik sebagai guru kelas, guru kegiatan ekstra kurikuler, tutor, dan lain-lain.

2) Personil pelayanan administrasi

Meliputi mereka yang mengarahkan, memimpin, dan mengawasi personil lain dalam operasi sekolah serta bagian- bagiannya.

3) Personil pelayanan fasilitas sekolah

Meliputi tenaga-tenaga diperpustakakan, pusat-pusat sumber belajar dan laboratorium bahasa; ahli-ahli teknik dan tenaga yang terlibat dalam fungsi mengajar atau fungsi melayani siswa.

13 Oteng Sutrisno. Administrasi Pendidikan. (Bandung: Angkasa. 1985), 65 
4) Personil pelayanan murid atau siswa

Meliputi pada spesialis yang tanggung jawabnya meliputi bimbingan dan penyuluhan, pemeriksaan psikologis dan kesehatan, nasihat medis dan pengobatan, testing dan penelitian, penempatan kerja dan tindak lanjut, serta koordinasi kegiatan murid.

b. Layanan bantu

Perubahan dinamika masyarakat yang cepat seperti yang kita alami saat ini, sekolah merupakan pemegang peranan penting, dengan memberikan banyak pelayanan yang diharapkan dari sekolah, antara lain adalah:

1) Pelayanan perpustakaan

Perpustakaan merupakan salah satu sarana pembelajaran yang dapat menjadi sebuah kekuatan untuk mencerdaskan bangsa. Perpustakaan mempunyai peranan penting sebagai jembatan menuju penguasaan ilmu pengetahuan. Perpustakaan memberi kontribusi penting bagi terbukanya informasi tentang ilmu pengetahuan.

2) Pelayanan gedung dan halaman sekolah

Dengan memlihara gedung sekolah secara sistematis dapat menghasilkan keuntungan yang besar bagi operasi sekolah. Hal ini dapat ditunjukkan dengan peningkatan pemeliharaan yang terus menerus untuk menjamin kondisi gedung sekolah yang paling baik. Sehingga dapat menciptakan suasana belajar yang nyaman, memajukan kesehatan dan keamanan, melindungi barang-barang milik sekolah, dan memajukan citra masyarakat yang sesuai.

3) Pelayanan kesehatan dan keamanan

Tujuan penting pendidikan disekolah adalah kesehatan fisik dan mental, maka sekolah memperkenalkan program Sekolah dikatakan berhasil jika mampu memberikan layanan sesuai harapan pelanggan. Dilihat dari jenis pelanggannya sekolah dikatakan berhasil jika:

a) Siswa puas dengan layanan sekolah, misalnya: puas dengan pelajaran yang diterima, puas dengan perlakuan guru maupun pimpinan, puas dengan fasilitas yang disediakan sekolah. 
Ali Mustofa

Andik Prayugo

b) Orang tua puas dengan layanan terhadap anaknya maupun layanan kepada orang tua, misalnya: puas karena menerima laporan periodik tentang perkembangan siswa maupun program-program sekolah.

c) Pihak pemakai/penerima lulusan (perguruan tinggi, industri, dan masyarakat) puas karena menerima lulusan dengan kualitas yang sesuai dengan harapan.

d) Guru dan karyawan puas dengan pelayanan sekolah, misalnya: dalam pembagian kewajiban kerja, hubungan antara guru/ karyawan/ pimpinan, honorarium/gaji, dan sebagainya.

\section{Analisis}

Pengembangan Sistem Informasi Manajemen pada lembaga pendidikan sangat dibutuhkan, karena dalam menghadapi persaingan global lembaga pendidikan dituntut untuk memberikan informasi lebih cepat, akurat dan nyaman yang merupakan bagian dari kualitas pelayanan, sehingga akan menjadi sebuah keunggulan bersaing. Layanan yang ditawarkan lembaga dapat ditingkatkan melalui unsur kualitas jasa. Lembaga pendidikan merupakan organisasi yang memberikan pelayanan kepada Stakeholder internal dan eksternal. Stakeholder internal terdiri dari semua lembaga di dalam sekolah (seperti yayasan, program studi, dan unit kegiatan siswa) dan para aktor yang berada di dalamnya (seperti siswa, guru, tata usaha, dan staf yang lain)

Implementasi sistem informasi managemen dalam mendukung pelayanan tenaga pendidikmencakup tiga aspek, yaitu;

1. Perencanaan merupakan salah satu syarat mutlak bagi setiap kegiatan administrasi pelayanan tenaga pendidik

2. Pelaksanaan adalah suatu tindakan atau pelaksanaan dari sebuah rencana yang sudah disusun secara matang dan terperinci, implementasi biasanya dilakukan setelah perencanaan sudah dianggap siap. Secara sederhana pelaksanaan bisa diartikan penerapan, yaitu implementasi sistem informasi managemen dalam mendukung pelayanan tenaga pendidik

3. Evaluasi merupakan penilaian terhadap hasil kerja yang telah dilaksanakan. Hasil penilaian, dijadikan sebagai acuan dalam melakukan perbaikan dan penyempurnaan, untuk mencapai tujuan yang telah ditetapkan. Dalam hal ini 


\section{Konsepsi Implementasi Sistem Informasi Managemen dalam Mendukung Pelayanan Tenaga Pendidik}

adalah untuk evaluasi implementasi sistem informasi managemen dalam mendukung pelayanan tenaga pendidik

\section{Kesimpulan}

Pemanfaatkan Sistem Informasi Managemen sebagai sistem pelayanan tenaga pendidik dan kependidikan. Yang dimana tenaga pendidik dan kependidikan akan dikelola dan diberdayakan melalui SIMPATIKA (Sistem informasi Pendidik dan Tenaga Kependidikan Kementrian Agama). Layanan SIMPATIKA sangat membantu dalam pengelolaan tenaga pendidik dan kependidikan, meskipun ada beberapa kelemahan didalamnya yang harus dihadapi. menggunakan SIM bukan hanya karena sebuah keharusan. Untuk merealisasikan visi, Meningkatkan kualitas tenaga pendidik dan kependidikan sesuai dengan standar pendidik dan kependidikan". Maka penggunaan SIM adalah bukan sekedar untuk dipergunakan, melainkan sebuah langkah wajib untuk menjalankan misinya. Pemeliharaan SIM harus diprioritaskan dalam rangka melayani pendidik dan tenaga kependidikannya demi terwujudnya kualitas tenaga pendidik dan kependidikan sesuai dengan standar pendidik dan kependidikan.

\section{Daftar Rujukan}

Shulhan, Muwaid H. S. 2018. Managemen Pendidikan Islam, Yogyakarta: Kalimedia.

Moekijat. 2005. Pengantar Sistem Informasi Manajemen, Bandung: Mandar Maju

Prasojo, Lantip Diat. 2013. Sistem informai Managemen Pendidikan, Yogyakarta: UNY PRESS.

Purwanto, Ngalim. 1998. Administrari Pendidikan, Jakarta: Mutiara Sumber Widya.

Setiawan, Guntur. 2014. Implementasi dalam Birokrasi Pembangunan, Jakarta: BalaiPustaka.

Siagian, Harbangan. 1989. Administrasi Pendidikan, Semarang: Satya Wacana.

Sulistriyorini. 2006. Manajemen Pendidikan Islam, Bandung: Elka.

Sutrisno, Oteng. 1985. Administrasi Pendidikan, Bandung: Angkasa. 
Ali Mustofa

Andik Prayugo

Syamsi, Ibnu. 1995. Pengambilan Keputusan dan Sistem Informasi, Jakarta: Bumi Aksara.

Tim Dosen Administrasi Pendidikan Universitas Pendidikan Indonesia. 2009. Manajemen Pendidikan, Bandung: Alfabeta.

Usman, N. Konteks. 2002. Implementasi Berbasis Kurikulum, Jakarta: aja Grafindo Persada. 